\title{
INHERITANCE OF DUN, BROWN AND BRINDLE COLOUR IN CATTLE
}

\author{
S. BERGE \\ Agricultural College of Norway, Vollebekk, Norway
}

Received 17.i.49

DuN, brown and brindle colours are not frequent among the cattle colours. As the source of data usually has been meagre, the genetics of these colours has not been clear and many different hypotheses have been put up.

In some of the Norwegian breeds these colours are frequent and it was found necessary to make a test.

\section{DUN COLOUR}

Dun is frequent among the colours of West-Coast cattle in Norway. The investigation was performed on data collected from the herd books of the breed and from the owners of herds of West-Coast cattle. For details see Berge (1948).

The frequency of the dun colour of bulls and cows in the herd books is given in table $\mathrm{I}$.

TABLE I

Percentage distribution of the colour of animals in the herd books of West-Coast cattle and of their parents

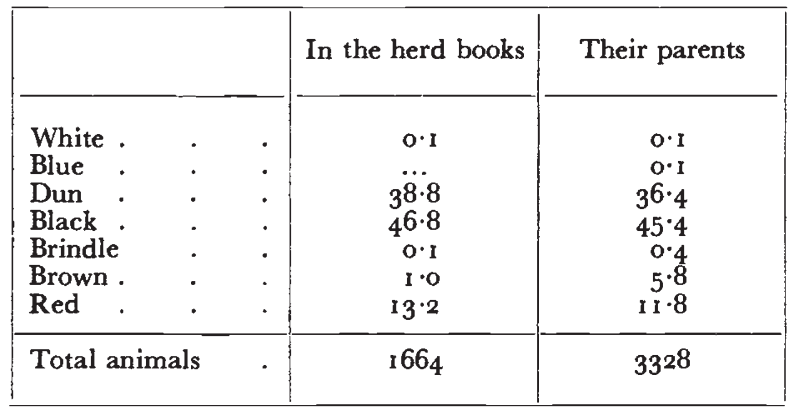

Hairs of the different types of dun were collected and examined. This examination showed the dun colour was a special case of agouti colour. Each hair had a varying number of lighter and darker zones. The zones vary in number and breadth also in adjacent hairs.

Two different types of dun are found, viz. dark dun and light dun. Usually in dark dun there are 2-3 zones with a dark-brownish pigment and the intermediary zones have a faint yellow or faint reddish colour. The top and often the base are clear white or almost transparent. 
In light dun the dark zones are considerably lighter or almost disappearing, and the intermediate zones are faded and yellow-whitish. colour.

Totally white hairs were found neither in dark-dun nor in light-dun

The dun colour is found in Indian humped cattle. An examination of the hairs of a light-dun "Zebu" cow (Bos indicus) in the zoological garden of Copenhagen 1947 showed the same agouti pattern as the dun in Norwegian cattle.

Apparently no difference was found between the two sexes in the segregation of dun colour.

Difference in colour between the sexes was slight. At birth the two sexes were alike, but full grown the bulls were of darker colour than the cows. This is the same tendency as in red and brown colour.

Dun is not often found in the breeds of cattle and consequently very few breeding experiments are found. Watson ( I $92 \mathrm{I}$ ) has reported crossings of Aberdeen-Angus and dun West Highland. The number of offspring was too small to make any final conclusion. Wright (I9I7) who first dealt with the genetics of dun suggested it was caused by an incomplete dominant factor $\mathbf{D}$ acting on black (B).

The effect of $\mathbf{D}$ on other colours than black has been subject of discussion. In the present investigation an ordinary red bull was found, which mated to black cows gave dun offspring and thus the dun factor evidently has no influence on red colour.

The colour of the offspring from the matings of West-Coast cattle is given in the table.

TABLE 2

Distribution of colour from the matings of West-Coast cattle. All shades of dun are combined

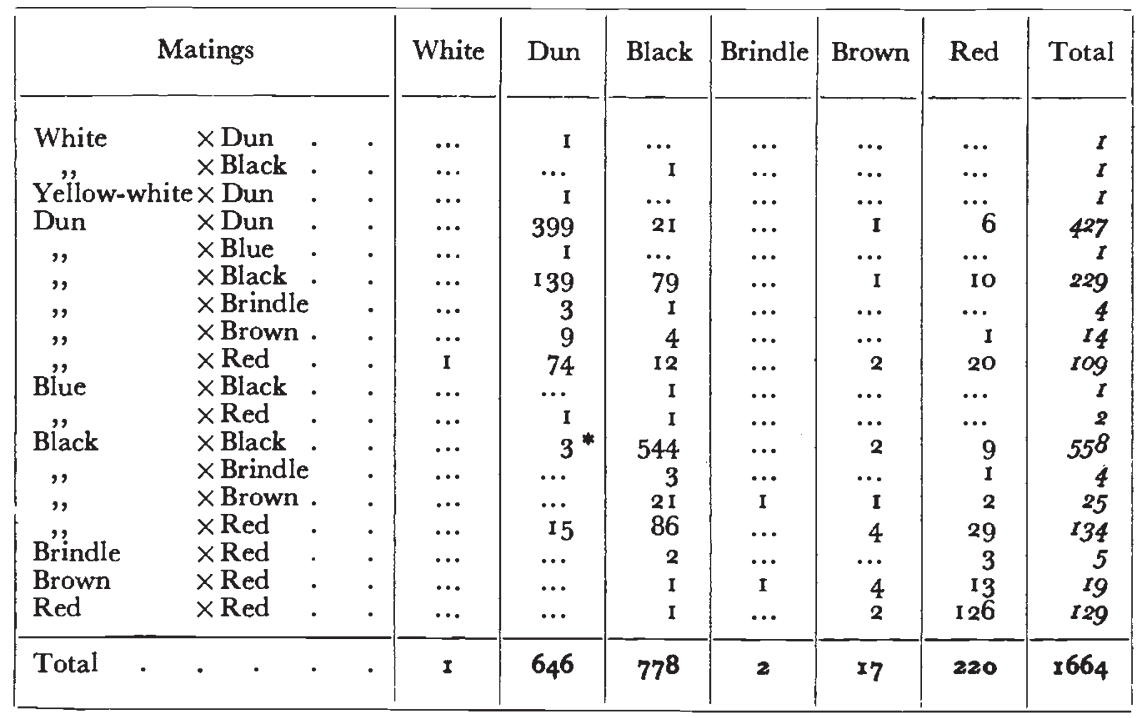

* Perhaps due to misstatement of paternity. 
The "blue" and "white" types probably are extreme light types of black sided. The yellow-white is probably diluted red.

With the exception of black by black and black by red, there are no duns from non-dun parents. The 3 duns from black by black were probably due to incorrect statement of paternity.

From black mated to red, I5 duns were found. These are too many to have been caused by wrong statements of parents or of colour. The best explanation is that some of the reds have been carrying the dilution factor $\mathbf{D}$ which has no influence on red.

The dun factor and the black factor (B) segregated independently Backcross of dun $F_{1}$ cows to red bulls showed :-

$$
\text { I } 3 \text { dun : } 9 \text { black : } 25 \text { red. }
$$

With respect to the dun factor the two types of dun, dark (the usual type) and light, were genetically alike, but with respect to shade they were genetically different. Light dun was caused by a recessive dilution factor, $i$, acting on dun and red colour, but not on black.

Light dun by light dun gave no dark duns and matings of red by light dun gave :-

I light dun : 27 dark dun : 9 not dun.

Duns homozygous for $\mathrm{i}$ were light dun and reds homozygous for i were yellow. As red was not a common colour, yellow was seldom found.

Yellow is an extreme dilution of red and recalls a yellow-white colour. Probably the diffuse red pigment, which is present in all coloured hairs, is diluted in the light dun and the yellow colour.

Red animals may be carriers of the dun factor, D, without any effect on red colour.

A type of light-red colour with very light muzzle, back, rear flank, belly, udder and inside of the thigh, is very common among the West-Coast cattle and in most of the Norwegian breeds. As the description of colour in the herd books was not sufficient as to the shades of red, genetical researches could not be done. So far it can be said, it was evidently neither the dun factor, $D$, nor the brown factor and probably not the dilution factor, $i$, which caused the lightred colour. This type of red is probably caused by a special factor or factors and the relation to the usual intense red is not known.

The following set up of factors may be found in dun, red and yellow concerning $\mathbf{B}, \mathbf{D}$ and $\mathbf{I}$.

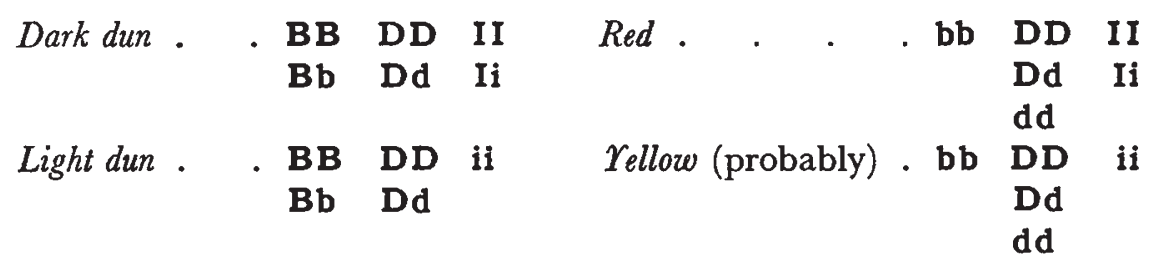




\section{BROWN AND BRINDLE}

Brown colour is common in "Dølefe," which is the leading breed of cattle in the mountainous parts of the Hedmark and Opland districts in Norway.

The brindle colour is not so common as brown, but is also found in "Dølefe." Both colours are also found in West-Coast cattle and in "Telemarkfe."

The brown colour varies between breeds and within breeds. The brown colour of the Norwegian breeds is different from the brown (fawn) in Jersey and is obviously the same brown colour which Cameron (r925) has called donn and according to Cameron was former common in West-Highland cattle. It is also different from the mahogany-brown, which according to Wright ( $19^{1} 7$ ) is dark red.

The brown colour is brought about by a special distribution of black and brown hairs. In the darker types of brown, the animal has a black body colour and a broad brownish portion from the withers along the back and tail extending to the sides of the body. The border between brown and black is not distinct except in the tail. There is usually a narrow black stripe in the middle of the back with brown parties on both sides. The black stripe is broken in the lumbar region and ends usually at the third coccygeal vertebra.

The brown portion is extended to the upper part of the sides and the rump.

The muzzle and tongue are dark, but over the muzzle there is a light greyish-white ring and usually greyish-white hairs are found in the groin on the udder and inside of the thighs. The lighter types of brown have more of the brown colour and lesser of the black. The lightest types of brown are not very different from the lightbrownish reds.

At birth the calves of both sexes are red. The brown colour will usually appear at the first shedding of hair at the age of three months. A dark-coloured tongue at birth is a sign of brown or brindle colour later.

As mature animals the bulls are usually darker than the cows.

The colour changes with the seasons. It is darkest after the hair shedding in the spring and usually turns lighter in the autumn and winter.

The hairs have no agouti pattern. The black hairs are totally black. The brown hairs are either all yellow-brown or yellow-brown at the top and the rest is black. The greyish-white hairs are all greyishwhite.

The brindle colour is a special distribution of black and red. In brindle the basic colour is red and the black is restricted to regular, transverse stripes forming a certain pattern.

The intensity of brindle differs considerably. In the most typical form, there are black stripes all over the body. In the lightest types 
the animal is red with a few black stripes on the croup and head and neck. These lighter types are often wrongly classified as reds.

The brindle calves are red at birth just like the brown. In the darkest type of brindle, the brindles will, as the brown colour, appear at the first hair shedding at the age of three months, but for the lighter shades of brindle the true colour will not appear until the animal is a year old or more. The classification of colour has accordingly to be done on mature animals.

The genetics of brown and brindle has not been fully clarified and different hypotheses are put up. Of the publications may be mentioned Wriedt (1918, 1919), who investigated brindle colour in "Telemarkfe" and Cole (1924, 1925) and Ibsen (1933) dealing with brown and brindle. Cole based his hypothesis on a cross of AberdeenAngus with Jersey and maintained the brown of Jersey cattle was determined by a factor dominant to red and recessive to black. Brindle was determined by a factor which had no influence on red and black, and beside this a special factor was necessary.

Ibsen (1933) maintained this special factor was the brown factor.

This hypothesis is in accordance with my researches in Norwegian cattle, and $I$ have used his denomination of the factors. The brown factor is denominated as $\mathbf{B}_{\mathbf{s}}$ (black spotting) and the brindle factor $\mathbf{B}_{\mathbf{r}}$.

An investigation into the genetics of brown and brindle requires a large number of crosses and backcrosses. If we have to make use of the herd-book data, the respective breed must have both colours and no tendency to counteract or to prefer any of them. As mentioned before the Norwegian "Dølefe" has both colours and black, brown, brindle and red are all allowed in the herd book.

TABLE 3

Percentage distribution of colour in herd-book animals of "Dolefe" and their parents. Herd book of "Dolefe," vol. r-9

\begin{tabular}{|c|c|c|c|c|c|c|}
\hline & \multicolumn{2}{|c|}{ Bulls } & \multicolumn{2}{|c|}{ Cows } & \multicolumn{2}{|c|}{ All } \\
\hline & $\begin{array}{l}\text { Herd } \\
\text { books }\end{array}$ & $\begin{array}{l}\text { Their } \\
\text { parents }\end{array}$ & $\begin{array}{l}\text { Herd } \\
\text { books }\end{array}$ & $\begin{array}{l}\text { Their } \\
\text { parents }\end{array}$ & $\begin{array}{l}\text { Herd } \\
\text { books }\end{array}$ & $\begin{array}{l}\text { Their } \\
\text { parents }\end{array}$ \\
\hline $\begin{array}{l}\text { Dun } \\
\text { Black : } \\
\text { Brindle : } \\
\text { Black-brown } \\
\text { Brown : } \\
\text { Red : }\end{array}$ & $\begin{array}{r}4 \cdot 4 \\
38 \cdot 1 \\
6 \cdot 8 \\
25 \cdot 8 \\
12 \cdot 6 \\
12 \cdot 3\end{array}$ & $\begin{array}{r}4 \cdot 8 \\
33 \cdot 7 \\
7 \cdot 2 \\
21 \cdot 2 \\
19 \cdot 5 \\
13 \cdot 6\end{array}$ & $\begin{array}{r}2.4 \\
39.4 \\
9.2 \\
12.8 \\
25.5 \\
10.7\end{array}$ & $\begin{array}{r}2 \cdot 6 \\
39 \cdot 8 \\
7 \cdot 2 \\
21 \cdot 4 \\
17 \cdot 0 \\
12 \cdot 0\end{array}$ & $\begin{array}{c}3 \cdot 1 \\
38 \cdot 9 \\
8 \cdot 4 \\
I 7 \cdot 5 \\
20 \cdot 8 \\
1 T \cdot 3\end{array}$ & $\begin{array}{r}3 \cdot 4 \\
37 \cdot 6 \\
7 \cdot 2 \\
21 \cdot 3 \\
17 \cdot 9 \\
12 \cdot 6\end{array}$ \\
\hline Total animals & 1128 & 2256 & 1999 & 3998 & $3^{127}$ & 6254 \\
\hline
\end{tabular}

From the published herd book, vol. I-9, the distribution of the colour of the herd-book animals and of their parents is examined. In the herd books the shade of brown is usually given. The darkest 
type is called black-brown. The rest is called brown or dark brown. As the distinction between the types is not always clear, there may be some error in the classification.

Because the bulls are darker than the cows, the calculation was made on each sex separately.

The difference between the percentage of parents and offspring is a measure of the selection. From the table it can be seen the selection is of little importance with exception of the brown colour, where the sex-dimorphismus is the cause of the large difference. Black-brown parents give about the double of black-brown bulls in relation to black-brown cows. The brown parents give the opposite relation for the two sexes. For both sexes the sum of black-brown and brown is about the same for parents and offspring.

This indicates the inheritance of the brown factor is the same in the two sexes and in the two types of brown, but the grouping of the matings of black-brown and brown showed the two types of brown to be genetically different. This difference was not in the inheritance of the brown factor, but was brought about by a special factor affecting the brown colour.

\section{TABLE 4}

Percentage distribution of the two types of brown colour in matings of black-brown and brown. Only the percentage of brown is considered. Herd book of "Dolefe," vol. I-9

\begin{tabular}{|c|c|c|c|c|c|c|c|c|}
\hline \multirow{2}{*}{ Matings } & \multicolumn{4}{|c|}{ Bulls } & \multicolumn{4}{|c|}{ Cows } \\
\hline & $\underset{\mathbf{n}}{\text { Total }}$ & $\begin{array}{l}\text { Black- } \\
\text { brown }\end{array}$ & Brown & $\begin{array}{l}\text { Sum of } \\
\text { brown }\end{array}$ & $\underset{\mathbf{n}}{\text { Total }}$ & $\begin{array}{l}\text { Black- } \\
\text { brown }\end{array}$ & Brown & $\begin{array}{l}\text { Sum of } \\
\text { brown }\end{array}$ \\
\hline $\begin{array}{l}\text { Black-brown } \times \text { Black-brown } \\
\text { Brown } \delta^{*} \times \text { Black-brown } 9 \\
\text { Black-brown } \delta^{\star} \times \text { Brown } \\
\text { Brown } \times \text { Brown }\end{array}$ & $\begin{array}{r}79 \\
8 \\
94 \\
70\end{array}$ & $\begin{array}{l}70 \cdot 9 \\
75 \cdot 0 \\
64 \cdot 9 \\
52 \cdot 9\end{array}$ & $\begin{array}{l}19 \cdot 0 \\
12 \cdot 5 \\
25 \cdot 5 \\
41 \cdot 4\end{array}$ & $\begin{array}{l}89 \cdot 9 \\
87 \cdot 5 \\
90 \cdot 4 \\
94 \cdot 3\end{array}$ & $\begin{array}{r}103 \\
23 \\
194 \\
83\end{array}$ & $\begin{array}{l}35 \cdot 0 \\
26 \cdot 1 \\
23 \cdot 2 \\
12 \cdot 0\end{array}$ & $\begin{array}{l}45 \cdot 6 \\
56 \cdot 5 \\
64 \cdot 4 \\
72 \cdot 2\end{array}$ & $\begin{array}{l}80 \cdot 6 \\
82 \cdot 6 \\
87 \cdot 6 \\
84 \cdot 2\end{array}$ \\
\hline
\end{tabular}

Matings of black-brown by black-brown give a high percentage of black-brown and low percentage of brown in both sexes. Matings of brown by brown give low percentage of black-brown and high percentage of brown.

The best explanation of this is offered by Wentworth (1916) on brown in the Ayrshire breed. He has suggested a sex-limited factor or factors. The same is found in the Jersey. According to the hypothesis a factor $\mathbf{M}$ gives dark-brown colour. This factor is dominant in the bulls. Its allelomorph, $\mathbf{L}$, gives light-brown colour and is dominant in cows. Heterozygote bulls are dark and heterozygote cows are light.

It is possible that the effect of the factors is in some extent intermediate, as it is not possible to classify the animals in two distinct groups as the theory implies. The variation of the brown colour 
through the seasons may be the cause or perhaps more than a single pair of factors are acting.

Concerning the inheritance of brown colour a combination of the two shades of brown was in any case justified.

This is done in the table of the matings.

TABLE 5

Distribution of colour from matings of "Dolefe." Black and dun are added in the black group, and all shades of brown are combined in the brown group. Herd book of "Dolefe," vol. $1-9$

\begin{tabular}{|c|c|c|c|c|c|c|c|}
\hline \multicolumn{3}{|c|}{ Matings } & Black & Brindle & Brown & Red & Total \\
\hline $\begin{array}{c}\text { Black } \\
\text { ", } \\
\text { ", } \\
\text { Brindle } \\
\text { ", } \\
\text { Brown } \\
\text { Red }\end{array}$ & $\begin{array}{l}\times \text { Black } \\
\times \text { Brindle } \\
\times \text { Brown } \\
\times \text { Red } . \\
\times \text { White } \\
\text { e } \times \text { Brindle } \\
\times \text { Brown } \\
\times \text { Red } . \\
\times \text { Brown } \\
\times \text { Red } . \\
\times \text { Red } .\end{array}$ & $\begin{array}{l}: \\
:\end{array}$ & $\begin{array}{r}645 \\
80 \\
417 \\
103 \\
1 \\
2 \\
10 \\
2 \\
38 \\
14 \\
3\end{array}$ & $\begin{array}{r}11 \\
38 \\
26 \\
25 \\
0 \\
20 \\
71 \\
20 \\
14 \\
32 \\
6\end{array}$ & $\begin{array}{r}65 \\
30 \\
239 \\
44 \\
0 \\
5 \\
82 \\
17 \\
571 \\
129 \\
15\end{array}$ & $\begin{array}{r}11 \\
8 \\
33 \\
57 \\
0 \\
1 \\
16 \\
21 \\
31 \\
73 \\
101\end{array}$ & $\begin{array}{r}732 \\
156 \\
715 \\
229 \\
1 \\
28 \\
179 \\
60 \\
654 \\
248 \\
125\end{array}$ \\
\hline Total & ${ }^{\circ}$ & . & $13 \times 5$ & 263 & 1297 & $35^{2}$ & $3^{127}$ \\
\hline
\end{tabular}

Rather a large number of black offspring from parents, which were none black, are found. Probably this is brought about by wrong classification of colour. Of the reasons mentioned in the description of brown the classification of brown, black and red is often difficult and is probably very often not correct and consequently the data from the herd books are not trustworthy as to the segregation of colour.

In order to get more reliable data it was decided to collect information from herds, where the colour of the animals could be controlled. Only backcross of brown and brindle $F_{1}$ animals to red were considered. These backcrosses were found, (I) from the herd books, (2) from milk-recording societies, where the controller could check the classification, (3) from a crossing and backcross of "Dølefe" to the Norwegian red and white cattle (NRF). This breed is the same as the Swedish red and white cattle (SRB).

Only mature animals were considered.

No blacks were found from either browns or brindles. Both characters are recessive to black.

From the segregation and recombination in the backcross it is evident the hypothesis suggested by Ibsen (1933) is the best explanation of the genetics of brown and brindle.

According to this, brown is determined by a factor, $\mathbf{B}_{\mathbf{s}}$, which is dominant to red and recessive to black. Brindle is determined by a 
factor, $\mathbf{B}_{\mathbf{r}}$, acting on the brown factor, $\mathbf{B}_{\mathbf{s}}$, and with no influence on red and black. As some of the red animals are carrying $\mathbf{B}_{\mathbf{r}}$, a certain percentage of the offspring in the backcross to brown, are brindle. In the brindle backcross the number of brindles of the same reason is larger than the browns.

TABLE 6

Backcross of brown and brindle $F_{1}$ animals to red

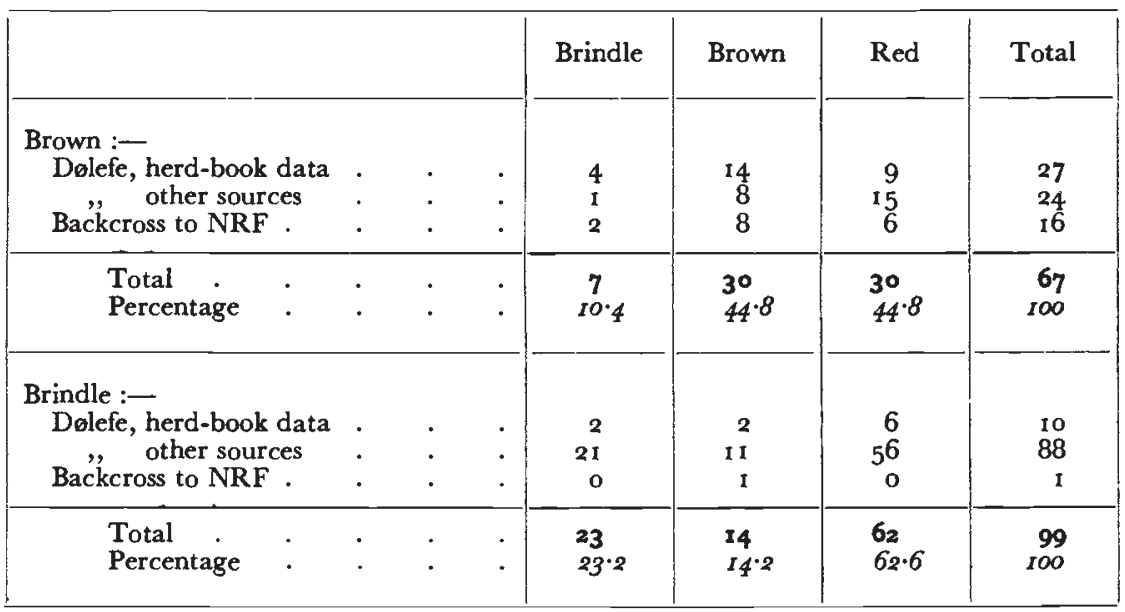

The backcross to brown is consequently :-

$$
\begin{array}{llll}
B_{s} b_{s} \quad b_{r} b_{r} \times & b_{s} b_{s} & b_{r} b_{r} \\
& b_{s} b_{s} & B_{r} b_{r} \\
& b_{s} b_{s} & B_{r} B_{r}
\end{array}
$$

The backcross to brindle is :-

$$
\begin{array}{lllll}
\mathbf{B}_{\mathrm{s}} \mathrm{b}_{\mathrm{s}} & \mathrm{B}_{\mathrm{r}} \mathrm{b}_{\mathrm{r}} & \times & \mathrm{b}_{\mathrm{s}} \mathrm{b}_{\mathrm{s}} & \mathrm{b}_{\mathrm{r}} \mathrm{b}_{\mathrm{r}} \\
& \mathbf{B}_{\mathrm{r}} \mathbf{B}_{\mathrm{r}} & \mathrm{b}_{\mathrm{s}} \mathrm{b}_{\mathrm{s}} & \mathrm{B}_{\mathrm{r}} \mathrm{b}_{\mathrm{r}} \\
& & \mathrm{b}_{\mathrm{s}} \mathrm{b}_{\mathrm{s}} & \mathbf{B}_{\mathrm{r}} \mathbf{B}_{\mathrm{r}}
\end{array}
$$

The frequency of $\mathbf{B}_{\mathrm{r}}$ in relation to $\mathbf{B}_{\mathrm{r}}+\mathrm{b}_{\mathrm{r}}$ in reds was calculated to 18.9 per cent. in the brown backcross.

In the brindle backcross the percentage of $\mathbf{B}_{\mathbf{r}}$ in the red animals was about of the same value.

In the brown backcross there was a little deficiency of reds. Fifty per cent. is expected and $44 \cdot 8$ per cent. was found. In the brindle backcross a large excess of reds was found. Fifty per cent. is expected and $62 \cdot 6$ per cent. was found. This excess of red in matings of reds to $F_{1}$ brindle was apparent in the offspring of all bulls, who had so many offspring that this matter could be examined.

The brown factor, $\mathbf{B}_{\mathbf{s}}$, was not an allel of the black factor, $\mathbf{B}$.

If we do not take into account the modifying factor or factors, 
which determine the shade of brown, the following combination of factors may be suggested concerning black, brown, brindle and red.

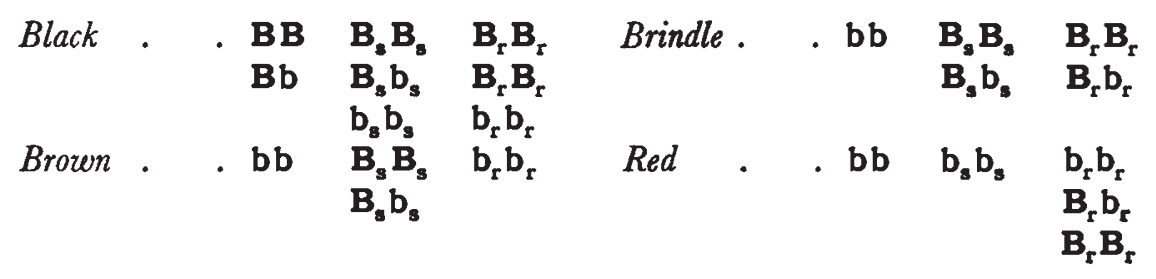

\section{SUMMARY}

Dun colour in West-Coast cattle in Norway is a type of agouti pattern. Each hair is banded. Genetically the dun colour is caused by a dominant factor $\mathbf{D}$ acting only when the factor for black is present. Backcross of dun $F_{1}$ cows to red bulls showed :-

$$
\text { I3 dun : } 9 \text { black : } 25 \text { red. }
$$

Light dun was caused by a special recessive factor acting on dun and red, but not on black.

Brown colour in "Dølefe" and probably other Norwegian breeds is caused by a factor, $\mathbf{B}_{s}$, dominant to red and recessive to black. The male sex is darker than the female. Backcross of brown $F_{1}$ animals to red showed :-

7 brindle : 30 brown : 30 red.

The seven brindles were caused by some reds carrying the brindle factor, which is hypostatic to red.

Brown in Norwegian cattle is probably the same colour as donn in West Highland.

Brindle colour in Norwegian cattle is caused by a dominant factor acting only on brown. The factor is called $\mathbf{B}_{\mathbf{r}}$.

Backcross of brindle $F_{1}$ animals to red showed :-

23 brindle : 14 brown : 62 red.

\section{REFERENCES}

BERGE, S. 1948.

Grå farge $\mathrm{i}$ vestlandsk fjordfe.

Tidsskrift f. d.n. Landbruk., 55, 219-240. Oslo.

CAMERON, JAMES. 1925 .

Transmission of colours.

Cattle Breeding, chapter vi, pp. 47-49. Edited by G. F. Finlay, Edinburgh.

COLE, L. J. I I924.

The Wisconsin experiment in cross-breeding cattle.

Proc. World's Dairy Congress, 1923, 2, 1383-1 388.

COLE, L. J. 1925.

Inheritance in cattle.

Cattle Breeding, chapter iii, pp. 26-46. Edited by G. F. Finlay, Edinburgh. 
IBSEN, HEMAN L. 1933 .

Cattle inheritance. I. Color.

Genetics, I8, 441-480.

WATSON, J. A. S. 1921 .

A Mendelian experiment with Aberdeen-Angus and West-Highland cattle.

7. Genet., II, 59-67.

WENTWORTH, E. N. 1916.

A sex-limited color in Ayrshire cattle.

7. Agr. Res., 6, 141-147.

WRIEDT, CHR. 1918.

Nedarving av farger hos telemarkfæet.

Norsk Landmandsblad, 1918, 496.

WRIEDT, CHR. I9I9.

The brindle colour in cattle in relation to red.

7. Genet., 9, 83 .

WRIGHT, SEWALL. 1917.

Color inheritance in mammals. VI. Cattle. 7. Hered., 8, $521-527$. 


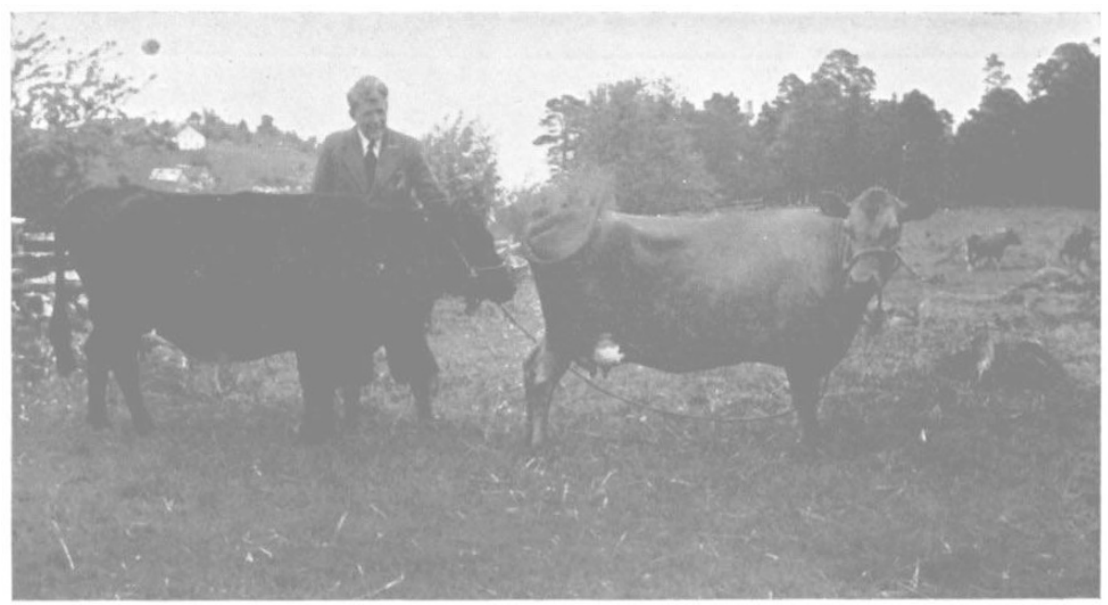

Fig. I.-Black cow (left) and dark-dun cow (right). West-Coast cattle. Photo by the author.

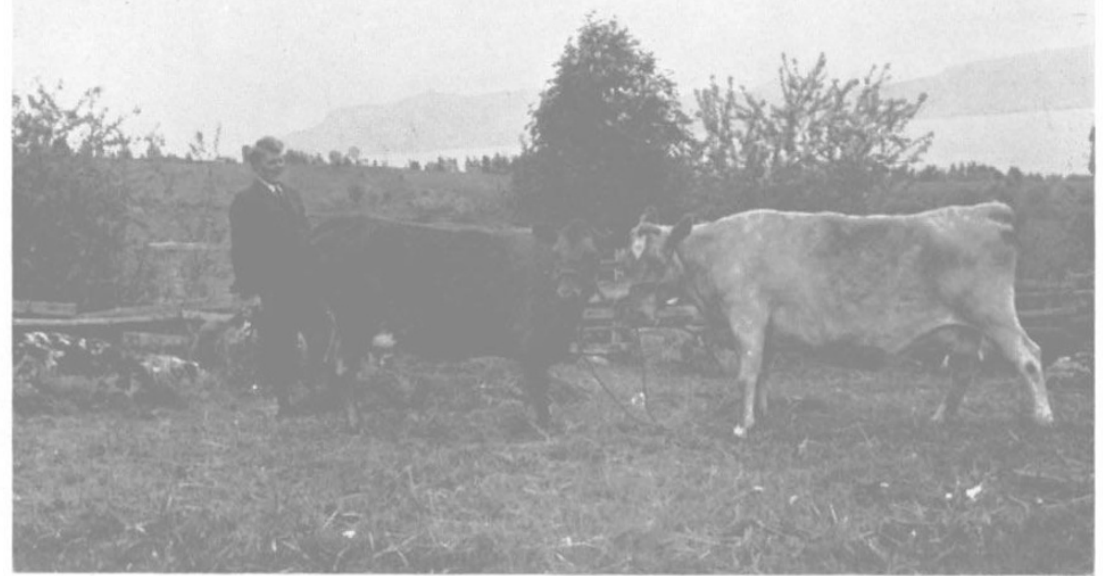

FIG. 2.-Dark-dun cow (left) and light-dun cow (right). The dark-dun cow is the same as in fig. 1. West-Coast cattle. Photo by the author.

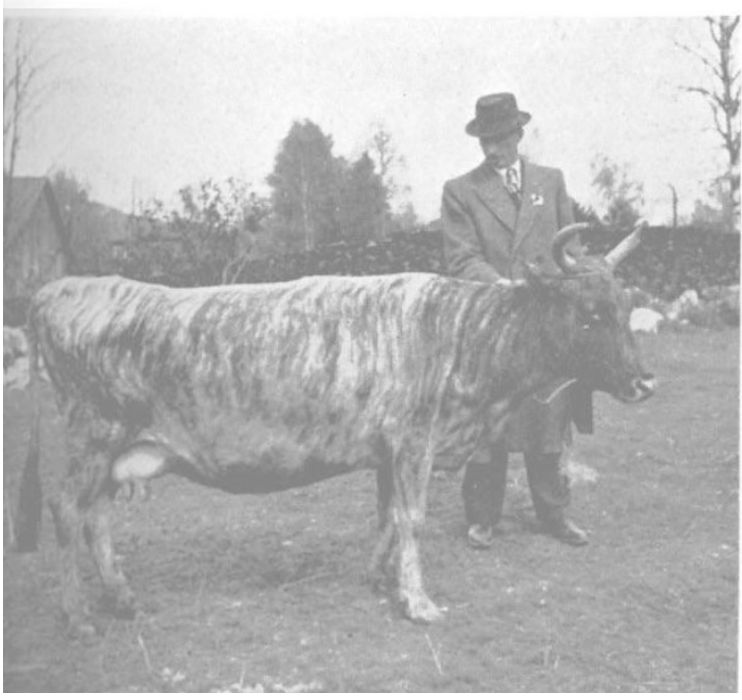

3. 3.-Brindle cow. Dølefe. Black stripes in brownish to light-yellowish colour.



Fig. 4.-Brindle cow. Dølefe. Same cow as in fig. 6, s from the air. The special pattern of the stripes are see 
FIG. 5.-Dark-brown heifer of Dølefe, born 25th November 1945. Photo August 1947 by the author.

Fig. 6.-Dark-brown cow. Same cow as in fig. 3. Photo 29th May 1948, five and half months after her first calving. The brown colour is considerably lighter than in fig. 3 . Photo by the author.

FIG. 7.-Dark-brown heifer. Same as in fig. 3 and 4. "Air view." Photo August 1947. The broad brown portion and narrow black stripe on the back are seen. Photo by the author. 

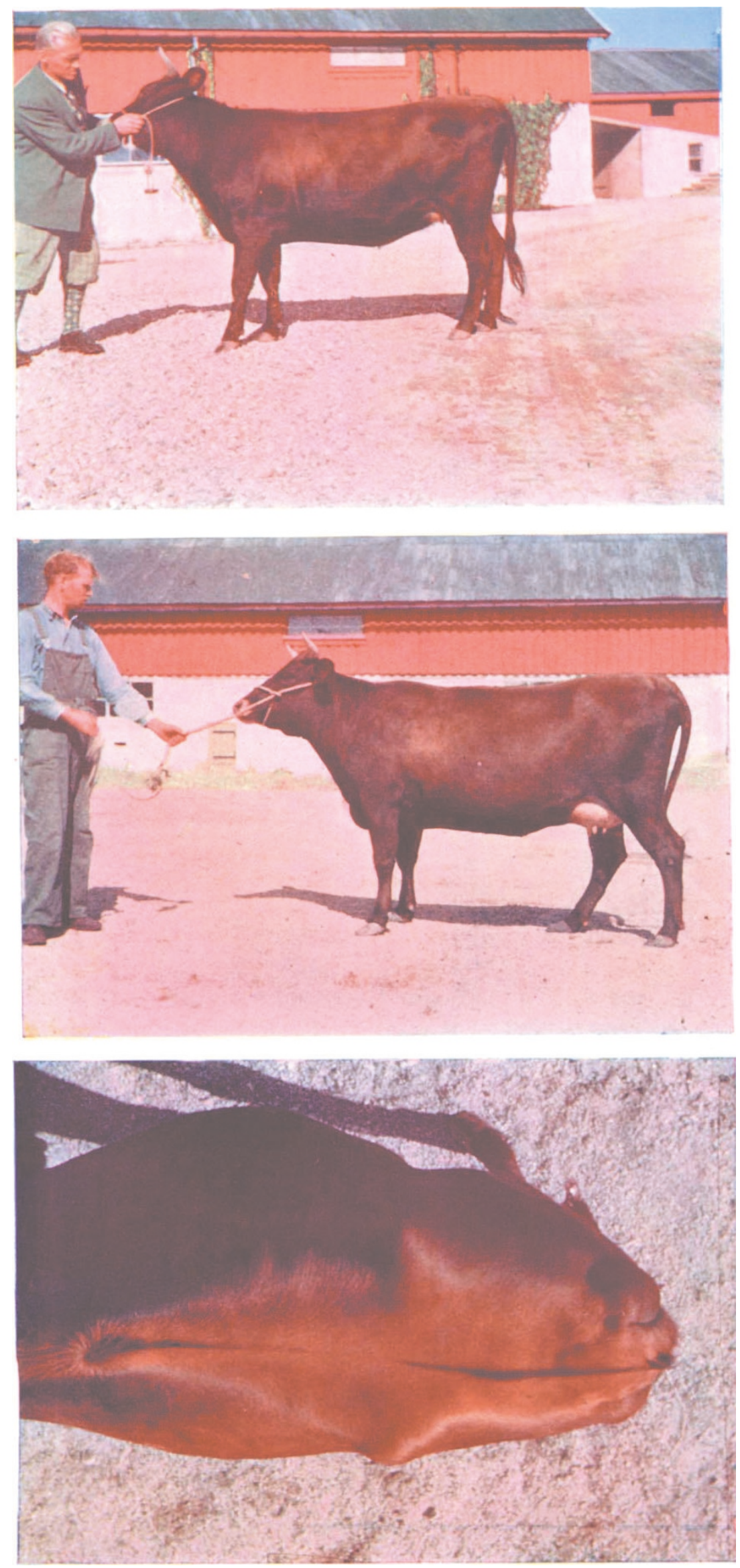